Pamiętnik Literacki 2015, 2, s. 71-93

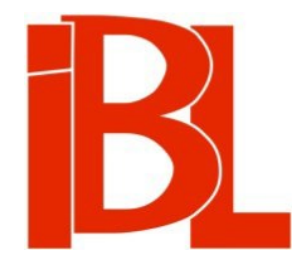

\title{
Bolesław Prus i wątpliwy blask postępu
}

Małgorzata Litwinowicz-Droździel 


\section{BOLESEAW PRUS I WĄTPLIWY BLASK POSTĘPU}

W roku 1910 Bolesław Prus opublikował felieton zatytułowany Co to znaczy postepp? W felietonie tym udziela odpowiedzi na to - skomplikowane, wydawałoby się - pytanie.

Po pierwsze, postęp jest snem. Prusowi śni się (jak zapewnia on: „legalnie i cenzuralnie"1), że był na jakiejś wystawie światowej - w Londynie czy w Paryżu. Zwiedzał tam gmach noszacy miano „Dzieje Postępu”. Na samym jego dnie, w suterenie, znajdowali się ludzie pierwotni, pozostający na etapie całkowitej dzikości. Parter oznaczony był nazwa „Dobrobyt” - charakteryzował się dostatkiem materialnym i „ogólnym stanem cywilizacji” (pola, domy, odzież). Na tym poziomie istniały już instytucje powołane do opieki nad słabszymi członkami społeczeństwa: starcami i dziećmi. W społeczności zamieszkującej „Dobrobyt” nie ma ludzi opuszczonych - każdy ma rodzinę i przyjaciół albo czuwa nad nim jakaś instytucja opiekuńcza. W tym pałacu przyszłości:

Prawie nie znano głodu, chłodu, braku odzieży, słowem - nędzy; naprzód bowiem istniały olbrzymie składy materiałów spożywczych, opałowych, tkanin, sprzętów, naczyń, a dalej zakłady, w których można było wykąpać się, odziać, najeść, przespać, usłyszeć koncert, odczyt lub kazanie, zobaczyć galerię obrazów albo widowisko teatralne.

Wszystkie owe składy, sklepy, instytucje łączyły się wygodnymi drogami, po których można było szybko przewozić ludzi i towary. Nadto zaś od parteru na pierwsze piętro i z pierwszego piętra do parteru prowadziły olbrzymie schody, ciągle zajęte przez publiczność. Jedni schodzili z piętra na dół, niosąc w rękach wyrobione przez siebie przedmioty: odzież, obuwie, pieczywo, sprzęty, książki, rękopisy, obrazy, nuty, słowem - wszystko, co ktoś sam wyprodukował. Ze swoim wyrobem każdy szedł do odnośnego składu, oddawał przedmiot i otrzymywał pieniądze; potem z pieniędzmi szedł do innych składów i kupował, co było mu potrzebne ${ }^{2}$.

Takich przejrzystych pałaców przyszłości do początku w. XX widziano już niemało. Pierwszym $z$ nich był Pałac Kryształowy, w którym odbyła się Wystawa Światowa w Londynie w r. 1851, kolejne wystawy w europejskich stolicach zawsze w jakiś sposób odnosiły się do ustanowionego przez Johna Paxtona wzorca: olbrzymie, przejrzyste konstrukcje $z$ żelaza i szkła, w których miał się pomieścić cały świat.

1 B. Prus, Co to znaczy postęp. W: Kroniki. Oprac. Z. Szweykows ki. T. 20. Warszawa 1970, s. 263. (Pierwodruk: „Tygodnik Ilustrowany” 1910, nr 45, z 5 XI).

2 Ibidem, s. 266. 
W swoim felietonie Prus zbiera rozmaite głosy i przeświadczenia epoki: pałac kryształowy stał się wzorcem organizacji czasu i przestrzeni, modelem życia i zamkniętym światem, którego zamknięcie można przeoczyć - jest on przejrzysty, a nieograniczona władza spojrzenia daje iluzję wolności i nieograniczonego posiadania przestrzeni.

Wyśniony przez autora Lalki pogodny przecież obraz społeczeństwa dobrze urządzonego i żyjącego dostatnio ma jednak kilka rys. Nie rys nawet, ale wręcz szczelin. Podłoga na piętrze „Dobrobyt” nie jest równa, lecz wypukła: najwyższa pośrodku, zniża się ku ścianom. Trzeba chodzić po niej ostrożnie, najlepiej korzystać przy tym z pomocy innych ludzi. Można - przy odrobinie nieuwagi - wpaść w szczelinę i znaleźć się piętro niżej: w suterenie prymitywu, wśród ludzi pierwotnych, i tak jak oni być wystawionym na głód, chłód, nędzę i inne niedole. Jak się okazuje, najczęstszymi ofiarami szczelin nie są ludzie niedołężni czy starzy, lecz próżniacy i złośliwcy, a także ulegający nałogom; to oni „nie zasługują na pomoc bliźnich, a spadłszy, stają się proletariatem”3. Ostatecznie więc ten sen szczęśliwy ma w sobie coś z koszmaru - świat dobrobytu nie jest ani stabilny, ani bezpieczny. Znalezienie się w nim nie oznacza osiągnięcia trwałej równowagi, noga może się w każdej chwili poślizgnąć, upadek w dzikość (proletariat?) jest tuż, tuż.

Niewielka pociecha płynie ze spostrzeżenia, że niebezpieczeństwo regresu w największym stopniu staje się udziałem próżniaków i tych wszystkich, którzy wyrzekają się uczestnictwa w świecie postępu. Prus nie był - o ile mi wiadomo - czytelnikiem Jeana-Jacques'a Rousseau, ale tropy kierujące nas w stronę oświeceniowej aksjologii postępu $\mathrm{z}$ pewnością można tutaj odnaleźć. Zasadniczo w większości koncepcji oświeceniowych postęp, po pierwsze, uważa się za zgodny $\mathrm{z}$ „naturą ludzka”, czymkolwiek ona jest. Po drugie - wyzwala on od nieszczęścia i zła, a wszystko, co do nich prowadzi, stanowi sprzeczność wobec idei postępu, gdyż jest ona moralna. Świat bardziej oświecony byłby jeśli nie idealnie szczęśliwy, to z pewnością do tego ideału zbliżony. Postęp intelektualny/cywilizacyjny i postęp moralny stanowią więc jedność ${ }^{4}$. W odczycie zatytułowanym $O$ odkryciach $i$ wynalazkach Prus właśnie to mówi: „razem z powiększeniem się odkryć i wynalazków, z polepszeniem się warunków bytu i ludzie stają się moralnie lepszymi" ${ }^{5}$. W tym - jak informuje karta tytułowa - „odczycie popularnym" ${ }^{6}$ Prus podaje jasna definicję postępu/rozwoju cywilizacji: „stopniowe doskonalenie się społeczeństw ucywilizowanych, [...] ciagły przyrost wiadomości o przedmiotach istniejących w naturze, [...] ciagłe powiększanie się ilości narzędzi i materiałów użytecznych [...]”. Tak rozumiany postęp pozwala ludzkości na wiele - przy czym samo pojęcie „ludzkości” jest przez Prusa traktowane dość osobliwie: „Odkrycie np. Ameryki i Australii oddało w ręce ludzkości przeszło 900 mil kwadratowych gruntu bardzo urodzajnego i bogatego, miejsca więc na mieszkanie nieprędko zabraknie"7 - najwyraźniej ziem

Ibidem.

Zob. B. B a c z k o, Rousseau: samotność i wspólnota. Gdańsk 2009, s. 122.

A. Głow a cki [B. Prus], O odkryciach i wynalazkach. Warszawa 1873, s. 8. Jest to tekst odczytu wygłoszonego 23 III $1873 \mathrm{w}$ Warszawie.

Ibidem, s. 5.

Ibidem, s. 6. 
Ameryki i Australii nie zajmowała „ludzkość”. Los mieszkańców tych nowych terytoriów jest jednak rzeczywiście nieludzki:

W Ameryce, a bardziej jeszcze w Australii, żyją plemiona tak ubogie, że mieszkają w norach, chodzą nago i jedzą nawet zdechłe i gnijące ryby i zwierzęta. Są plemiona tak dzikie, że pożerają nie tylko swoich nieprzyjaciół, ale nawet własne dzieci. Ludzie ci są tak ograniczeni, że język ich posiada zaledwie kilkaset wyrazów, że więcej niż do stu doliczyć nie mogą, że wreszcie zupełnie nie zdają się być zdolni do przyjęcia europejskiej cywilizacji ${ }^{8}$.

Los tych ludów - jak pisze Prus - choć przerażający, jest już przesądzony. Niezdolne nie tylko do zrozumienia idei postępu, lecz także do prostszej umiejętności - czyli przyjęcia i stosowania odkryć i wynalazków - znikną one z powierzchni ziemi.

Nie wydaje mi się, by w duszy Prusa (jeśli w ogóle w tej kwestii można się wypowiadać) grały nazbyt głośno nuty imperialne, pragnienie podbojów i ekspansji. Trzeba - to oczywiste - pamiętać o języku, na którego użycie pozwalała epoka ${ }^{9}$; myślę zresztą, że Prusa stosunek do kolonizacji i język, którym się posługuje, by o tym pisać, to oddzielny temat, niewątpliwie zasługujący na uwagę i wart rozwinięcia. Nie do zignorowania jest też aspekt taki, jak poetyka odczytu (popularne wystąpienie, które powinno być zrozumiałe dla niespecjalistów i charakteryzować się pewną wyrazistością retoryczna) oraz felietonu - formy krótkiej, przewrotnej, w przypadku Prusa prawie zawsze zaczepnej, polemicznej wobec innych głosów i opinii.

Całość wywodu w odczycie Prusa prowadzi jednak do spostrzeżeń i wniosków dotyczących społeczeństwa polskiego. Ostry obraz „dzikich”, którzy będą starci z powierzchni ziemi w momencie nadejścia „ludzkości”, zostaje odwrócony i przeniesiony - dość niespodziewanie - w niepokojąco bliskie okolice. W ostatnich, wieńczących całość wystapienia akapitach Prus zaczyna mówić o polskim „niedołęstwie" 10 i rozmaitych zagrożeniach, które wiążą się z konsekwentną niezgodą na uczestnictwo w nowym wspaniałym świecie:

Ten, kto kieruje młotem parowym, musi być o wiele ukształceńszy od tego, który bije młotem zwykłym. Maszynista na statku parowym bez porównania musi więcej umieć od przewoźnika. [...]

Ile razy do nas sprowadzą nową machinę, tyle razy i ludzi trzeba przy niej z zagranicy sprowadzać, a to dlatego, że miejscowy nieukształcony robotnik rady sobie $z$ tą machiną nie da, nie może zrozumieć jej ruchów, nie potrafi nią pokierować, nie umie jej naprawić, gdy się zepsuje ${ }^{11}$.

Ibidem, s. 9.

O uprawianych w XIX w. „strategiach racjonalizacji” kolonizacji pisze np. S. Li in d qu i s t w książce Wytępić cate to bydło (Przeł. M. H a y k ow s ka. Warszawa 2009). W pracy tej autor przytacza m.in. wystapienie F. Farrara w Londyńskim Towarzystwie Antropologicznym (27 III 1866). Prelegent mówił o tym, że wszystkie rasy można podzielić na trzy grupy: dzikie, częściowo ucywilizowane i cywilizowane. Do tej ostatniej grupy należą jedynie rasy semicka i aryjska. Pozostałe - rasy dzikie - żyły zawsze w niewiedzy i nędzy: „Nie mają one ani przeszłości, ani też przyszłości. I tak jak inne, choćby i o wiele szlachetniejsze, żyjące na długo przed nimi, skazane są na szybkie, totalne i nieuniknione unicestwienie, co być może jest etapem w drodze do ostatecznego przeznaczenia ludzkości" (ibidem, s. 183).

Głow a cki, op. cit., s. 24.

Ibidem, s. 23. 
Te dwa teksty - odczyt O odkryciach i wynalazkach i felieton, w którym pojawia się sen o wystawie światowej - dzieli niemal 40 lat. Prus w r. 1873 jest początkującym dziennikarzem, jego działalność felietonistyczna dopiero się kształtuje, a twórczość literacka to dość odległa i niepewna - z tamtej perspektywy - przyszłość.

Cztery dekady twórczości autora Kronik to okres bardzo intensywnych zmian w sposobach komunikowania się, podróżowania czy w tym wszystkim, co można by nazwać „obsługa życia codziennego”. Gdy Prus zaczyna pisać i publikować regularnie swoje felietony, od uruchomienia pierwszej linii kolejowej w Wielkiej Brytanii (1825) mija pół wieku, niemal tyle samo od narodzin fotografii (1826: Widok z okna w Le Gras Josepha Nicéphore’a Niépce'a). Dekadę później pojawia się wynalazek Louisa Jacques'a Daguerre'a (1837).

W roku 1844 powstaje Kolej Warszawsko-Wiedeńska (polski odcinek to: Warszawa-Kutno-Włocławek-Aleksandrów-Ząbkowice-Sosnowiec). W latach czterdziestych do telegrafii zostaje wprowadzony kod składający się z kresek i kropek, znany powszechnie jako alfabet Morse'a, i uruchomiona zostaje w Stanach Zjednoczonych pierwsza linia telegraficzna. W roku 1855 z Konstantynopola do Paryża można już wysłać wiadomość telegrafem. Kabel transatlantycki pomyślnie zainstalowano w r. 1866 i stary świat połączył się z nowym. Kalendarium odkryć i wynalazków w tym okresie pęcznieje $z$ każdym rokiem, nie będziemy ich wszystkich wymieniać.

W Egiptian Hall w Londynie w roku 1892 zaprezentowany zostaje „Apparatus for producing stage illusions” - autorami wynalazku byli John Nevil Maskelyne Jr. i Charles Morrit. Przypadek rodziny Maskelyne jest ciekawy: jej członkowie zajmowali się sztukami iluzjonistycznymi. John N. Maskelyne senior był zegarmistrzem, a jego praktyczne umiejętności oraz wiedza o tym, jak działają drobne i precyzyjne mechanizmy, pozwoliły na zdemaskowanie jednego ze słynnych amerykańskich spirytystów z „The Davenport Brothers” (znanych z tzw. Cabinet of Dark Séance). Razem z George’em Cookiem założyli spółkę, którą określali jako „Royal Illusionists and Anti-Spiritualists”. Organizowali pokazy „sztuczek” - lewitacji, znikających przedmiotów. W roku 1873 John Maskelyne senior otworzył pracownię w Egyptian Hall w Londynie. Współpracował z najlepszymi iluzjonistami swoich czasów, a z jego pomysłów korzystał również Georges Méliés. Maskelyne opatentował kilkadziesiąt różnych urządzeń, wśród nich także „praktyczne”, jak jedno z rozwiązań klawiatury maszyny do pisania (klawisz Shift), zamek na monety do publicznych toalet czy maszyny do sprawdzania biletów, ale wśród zgłoszonych przez niego były i patenty na iluzję sceniczną. Sama idea „patentu na sztuczkę” jest wewnętrznie sprzeczna: sztuczka polega przecież na tym, że nikt nie wie, na czym ona polega. Patent - na tym, że mechanizm zostaje bardzo dokładnie opisany. Maskelyne'owie opatentowali m.in. trik, w którym pozornie obcinano kończyny wystające $z$ zamkniętej skrzyni (ręce i nogi były projekcją); iluzja opatentowana przestaje być „cudownością", staje się techniką, a prawo do używania jej można kupić wraz z instrukcją obsługi.

Rok wcześniej (1891) w USA Elijah Jefferson Bond z Baltimore rejestruje „The Quija Board"T" - tabliczkę do komunikowania się z duchami.

Interesująca i tajemnicza; niezrównana w przepowiadaniu przyszłości, czytaniu w umysłach, jasnowidzeniu; udziela inteligentnych odpowiedzi na wszystkie pytania. Sprawdzona w praktyce przed 
opatentowaniem. Cena $\$ 1,50$. We wszystkich najlepszych sklepach z zabawkami, pasmanteriach i sklepach papierniczych

- mówiła ulotka reklamowa ${ }^{12}$. Urządzenie służące do porozumiewania się z zaświatami i dające szanse uzyskania odpowiedzi na każde pytanie można więc było nabyć w jakimkolwiek sklepie za cenę naprawdę niewysoką. Patenty na perpetuum mobile to oddzielny temat; pojawiło się ich bardzo wiele, a wysiłki inżynierów, uczonych, popularyzatorów nauki - by przekonać entuzjastów wynalazku, że przeczy on znanym już prawom przyrody - spełzały na niczym. Jak wszyscy pamiętamy, konstruktorem takiej maszyny był również Stanisław Wokulski. Miała działać do końca świata, ale coś się w niej zepsuło po 15 minutach - jak objaśnia Rzecki. Pomysłów, które z perspektywy czasu okazały się nie całkiem trafne albo niezbyt zbieżne $\mathrm{z}$ rzeczywistością, było wśród wynalazków XIX w. bardzo wiele - choćby projekt komunikacji balonowej czy zaprezentowane w 1887 r. urządzenie, które za pomocą delikatnych impulsów elektrycznych miało leczyć ws zystkie choroby (nazywało się po prostu „Apparatus for treating diseases”, autorem patentu był Hercules Sanche $z$ Nowego Orleanu).

Podane przykłady to pewien wybór - to jasne. Sądzę jednak, że nawet ta krótka lista pokazuje, jak zróżnicowane były praktyki „wynalazczości” i w jak wielkie pomieszanie mogły wprawiać użytkowników. Termin „użytkownik” jest zresztą bardzo nieprecyzyjny, bo w polskim wieku XIX więcej było „czytelników” wynalazków niż ludzi, którzy mieli rzeczywisty kontakt ze wszystkimi tymi nowościami $\mathrm{i}$ w istocie $\mathrm{z}$ nich korzystali. Źródłem wiedzy o świecie postępu była w dużym stopniu prasa, doświadczenie - w stopniu znacznie mniejszym. W kalendariach XIX-wiecznej wynalazczości występują obok siebie przełomowe osiagnięcia (np. kolej czy nowe media), drobne, acz ważne wynalazki praktyczne (typu: otwieracz do konserw, kapsel, aspiryna, żywność instant), projekty całkowitej zmiany świata, możliwej dzięki opanowaniu jakiejś wszechzasady (perpetuum mobile, metal lżejszy od powietrza, lek na wszystkie choroby), oraz odmiany tychże epokowych wynalazków i odkryć sprowadzone do wymiarów kultury popularnej - wczesnej kultury masowej (tabliczka „Quija” za 1,50 dolara).

Nie wiem, czy możliwe do odtworzenia jest to, w jaki sposób wiadomości o wszystkich tych cudownościach były odbierane.

Pierwszy odcinek Lalki został opublikowany w „Kurierze Codziennym” 2 IX 1887, we czwartek. Kolejne odcinki powieści ukazywały się do 24 V 1889. Lektura tych wybranych roczników gazety przypomina o tym, jak istotna jest różnica między powieścią w odcinkach a powieścią-książka - jakkolwiek banalnie brzmi to stwierdzenie. I nie chodzi tutaj o zabiegi kompozycyjne i pisarskie strategie, lecz o to, co nazwałabym „środowiskiem”, które obejmuje nie tylko teksty prasowe, ale i układ graficzny czy też sposoby konstruowania i porządkowania informacji. Szczególnie znacząca wydaje mi się tutaj różnorodność porządków czasowo-przestrzennych i związana $z$ tym niejednolitość i nierównomierność obszarów podlegających zmianie modernizacyjnej.

Tak się akurat złożyło, że pierwszy odcinek powieści Prusa ukazał się w tym 
samym numerze, w którym redakcja donosiła $\mathrm{z}$ dumą o nadejściu „w dniu onegdajszym” maszyny pospiesznej, czyli rotacyjnej, dla „Kuriera”. Ma ona tłoczyć 10 tys. egzemplarzy na godzinę, za 14 dni zostanie uruchomiona, zajda wielkie zmiany w druku i w papierze - powiadamiają Gebethner i Wolff. Zapowiedź znaczącego przyspieszenia $w$ produkowaniu i dystrybuowaniu wiadomości sąsiaduje $z$ początkiem pierwszej polskiej powieści nowoczesnej. Ludzie będą czytać więcej i szybciej, zwiększy się też poważnie liczba użytkowników prasy, ponieważ dzięki tej innowacji zdecydowanie wzrośnie nakład dziennika. Lalka wchodzi więc od razu w ten przyspieszony i rozszerzający się obieg.

Czas w końcówce w. XIX mocno przyspiesza i zaczyna się go coraz dokładniej mierzyć. Pod winieta „Kuriera”, w środkowej części strony, znajduja się informacje o porze wschodów i zachodów słońca oraz księżyca na najbliższe dni, a także o całkowitej długości dnia, z dokładnością „chronometryczno-astronomiczną" - np.: słońce wschodzi o godz. 6 minut 01; czas zajścia księżyca podany jest z równą dokładnością. Doświadczenie, na którego podstawie można było oznaczać początek dnia i nocy (wiemy przecież, nawet dziś, że zachód słońca i nadejście nocy nie mają charakteru „nagłego”, lecz są rozciagnięte w czasie) ustępuje chronometrowi i dyktowanym przez niego ustaleniom. Szara godzina - interwał między dniem a ciemnością - zostaje zastapiona przez oznaczenie urzędowe, przez oficjalną i podaną na piśmie informację. Jaką wartość miała tego rodzaju wiedza, czerpana z prasy, w latach osiemdziesiątych XIX wieku? Praktycznego raczej nie - trudno mi sobie wyobrazić jej bezpośrednie, powszechne zastosowania. Jednak przeświadczenie o tym, że świat został ostatecznie zmierzony i opisany, mogło towarzyszyć czytelnikom, którym zabudowa miejska zasłaniała horyzont na tyle, by o końcu dnia dowiadywali się nie $z$ własnej obserwacji, ale $z$ codziennej gazety. Na tej samej wysokości strony, tuż obok astronomicznej wykładni wschodów i zachodów, redakcja podaje dni świętych patronów („dziś św. Remigiusza, bis. męcz., jutro św. Najś. M.P.Różań., pojutrze Kandyda męcz.”), po prawej - imieniny z kalendarza „świeckiego"13. Sądzę, że można potraktować to jako świadectwo przeplatania się różnych porządków czasowych: kalendarz liturgiczny używany jest równolegle $z$ kalendarzem astronomicznym, ten zaś z jeszcze innym, który nazwałabym miejsko-towarzyskim. Czytelnicy „Kuriera Codziennego” funkcjonowali w tych wszystkich porządkach. Dodać tu musimy jedną rzecz: zamieszanie wynikające $z$ równoczesnego stosowania kalendarza juliańskiego i gregoriańskiego ${ }^{14}$. Mówiąc o polskim wieku XIX, uważamy tę podwójność kalendarza za kwestię oczywistą, mnie wszakże wydaje

Zob. A. Tuszyńs ka, Rosjanie w Warszawie. Warszawa 1992, s. 69, s.v. Kalendarz juliański. Tzw. stary styl, jako urzędowy, stosowany był w w. XIX i XX jedynie w zaborze rosyjskim. Władze zaczęły go wprowadzać na zajętych terenach już po rozbiorach, jednakże w okresie konstytucyjnym Królestwa Polskiego posługiwano się kalendarzem gregoriańskim (tzw. nowym stylem). Podwójne datowanie weszło do użycia powszechnego po powstaniu listopadowym (choć korespondencję nieurzędową datowano według nowego stylu). Po powstaniu styczniowym stary styl stał się jedynym obowiązującym w obiegu urzędowym. Do roku 1915 datowano tak pisma, rozporządzenia, prasę. W wieku XIX (liczonym od 1 III 1800) różnica między datowaniem starego i nowego stylu wynosiła 12 dni, w w. XVIII - 11, w w. XX - 13 (te przesunięcia to skutek rozbieżności w określaniu lat przestępnych). 
się ona dodatkową zmienną $\mathrm{w}$ tamtym ruchliwym świecie. Wyrazem tego zamętu jest zresztą sposób umieszczania daty na tytułowej stronie „Kuriera”. W niektórych numerach z r. 1889 wygląda to następująco: nad winietą mamy linijkę o takiej zawartości - od lewej: data dzienna zapisana jako „ułamek” (23 września / 5 października 1889, przy czym czcionka jest tutaj tak mała, że właściwie nieczytelna), Warszawa (kapitalikami), w dalszej kolejności powtórzona zostaje data dzienna „5 października 1889”. Mamy więc w jednym wierszu datę dzienną podaną trzykrotnie.

„Kurier” zamieszcza także rozkłady jazdy pociagów. W roku 1887 większość pociągów odchodzi z Warszawy o godzinach podzielnych przez pięć; zdarzają się też połączenia „naprawdę nowoczesne”: pociagi Kolei Warszawsko-Petersburskiej odjeżdżają o 10.03, 11.33, pociag pocztowy do Mławy o 6.57. W miarę upływu lat te minutowe interwały zaczynają mieć coraz większe znaczenie - rozkłady jazdy publikowane w tym samym piśmie dwa lata później są pełne takich „nieokragłych” oznaczeń czasu.

Właśnie wtedy trwał na całym świecie proces ujednolicania czasu, tak charakterystyczny dla kolejowego uniwersum. Proces ten wszakże okazał się długi i skomplikowany, a odpowiedzi na pytania: „Która godzina?” oraz „O której odjeżdża pociąg?" - naprawdę nie były jednoznaczne. Konieczność standaryzacji czasu wiązała się w oczywisty sposób $\mathrm{z}$ rozwojem sieci kolejowych i telegraficznych, przede wszystkim w Stanach Zjednoczonych i w Europie. Pod koniec XIX stulecia liczba „czasów lokalnych” była jednak wciąż bardzo duża. Jeszcze około r. 1870 podróżny przemieszczający się $z$ Waszyngtonu do San Francisco musiałby przestawiać zegarek ponad 200 razy, gdyby chciał go uzgodnić z zegarami dworcowymi na mijanych stacjach! W roku 1884 w Waszyngtonie odbyła się Prime Meridian Conference, ustanowiono Greenwich jako południk zerowy, określono długość dnia, podzielono ziemię na 24 strefy czasowe, różniące się między sobą o godzinę. Ale - ustalenia te nie przyjęly się wcale tak szybko, a za moment narodzin czasu uniwersalnego wypada uznać dopiero 1 VII 1913, gdy z wieży Eiffla wysłano sygnał czasu, który obiegł cały świat. Tak skończyła się era „niepodległości” czasów lokalnych ${ }^{15}$.

Umieszczam tutaj tę dygresję nie tylko dlatego, że wydaje mi się interesująca kwestia lokalnych doświadczeń czasu wypartych przez czas precyzyjnie mierzony, standaryzowany, ustanawiany zawsze w jakiejś „centrali”, więc dany z zewnątrz i w pewien sposób zawsze oderwany od doświadczenia. Równie ciekawy jest ten przedziwny porządek przejściowy, w którym stopniowo rozkwitajacy ład globalny w końcu XIX stulecia łączył się ciagle $z$ doświadczeniem lokalności - nawet w warunkach warszawskich, specyficznie wielkomiejskich. Taki zaś dziennik jak „Kurier” odwoływał się do tej wielorakości porządków i doświadczeń, a ślady niejednolitości doświadczenia czasu są w tym piśmie w epoce Lalki wyraźne.

W „Kurierze Codziennym” znajdujemy np. informacje o repertuarach teatralnych, nie podaje się jednak ani godzin rozpoczęcia spektakli, ani adresów poszczególnych scen - w wypadku Teatru Wielkiego i Rozmaitości. Przy Teatrze Nowym mamy wskazanie: „ul. Królewska” (bez numeru), ,godzina 7 i 1 1/2 wieczór”. Pod koniec 
lat osiemdziesiątych ta część dziennika zostaje nieco rozbudowana i drukuje się pełną obsadę spektakli. O której chadza się do teatru i gdzie który z nich się znajduje - to jednak nadal wiedza zwyczajowa, jej standaryzacja nie jest konieczna. Informacje o czasie wydarzeń redakcja podaje tylko wtedy, gdy nie są one częścią wiedzy lokalnej:

Zgromadzenia: Zebranie uczestników spółki owocarskiej, lokal Towarzystwa ogrodniczego Chmielna 14 , o godz. 6.00 po południu.

Otwarcie sklepu stowarzyszenia Merkury dla robotników fabrycznych na Solcu, Zakłady Fabryczne Lilpop, Rau i Loewenstein, o godzinie 11.00 przed południem.

Wystawy: Towarzystwa Zachęty Sztuk Pięknych - od 10.00 do 6. Wystawa obrazów A. Krywulta w Hotelu Europejskim - od 6 rano do zmierzchu.

Wystawa nasion w Muzeum przemysłowo-rolniczym, od 10.00 do $5^{16}$.

Jedyna instytucja, której adres w tym komunikacie podano, to Towarzystwo Ogrodnicze, reszta lokalizacji musiała być oczywista dla czytelników - potencjalnych widzów i uczestników zapowiadanych wydarzeń. Godziny zostają określone, wszakże przy wiadomości o wystawie w Hotelu Europejskim pojawia się czas oznaczany nie urzędowo, ale zwyczajowo: „do zmierzchu”.

Ten kalendarz interesujących wydarzeń miejskich, umieszczony na pierwszej stronicy dziennika, zostaje w części powtórzony na stronicy kolejnej. Ponownie ukazuje się ogłoszenie o otwarciu sklepu na Solcu: „Jeszcze raz przypominamy o odbyć się mającym w dniu dzisiejszym zebraniu uczestników spółki owocarskiej" - oznajmia redakcja, co uświadamia nam, że podwójne zawiadomienie o otwarciu sklepu nie jest przeoczeniem, ale zabiegiem celowym. Przy tym tryb wyraźnie się tutaj zmienia. O ile przywołany tu kalendarz z pierwszej stronicy ma charakter „obiektywizującej się" informacji prasowej, o tyle powtórzone zawiadomienia sa już bardzo wyraźnym głosem redakcji, zachęcającej czytelników do wzięcia udziału $\mathrm{w}$ zapowiadanych wydarzeniach. Jest $\mathrm{w}$ tym pewien ton charakterystyczny dla gatunku ustnego znanego jako „ogłoszenia duszpasterskie” - słychać niemal głos czytającego zza pulpitu zatroskanego redaktora: „Jeszcze raz przypominamy...”

To samo pismo publikuje regularnie obszerny dział zatytułowany Telegramy „Kuriera Codziennego”. W jednym z numerów mamy tutaj doniesienia z Krakowa, Wiednia i Budapesztu - o wizytacji ministra oświaty Gautscha w szkołach krakowskich i pracowni Matejki oraz skrót mowy tronowej cesarza Franciszka Józefa w parlamencie węgierskim; są też telegramy z Paryża o jakiejś sprawie, w której wyniku strażnik niemiecki Kaufman zastrzelił pod Raons dojeżdżacza Brignona i zranił porucznika Wagena, następnie zbiegł („wiadomość dosyć nieprawdopodobna" - brzmi redakcyjny komentarz). Jaka jest logika informacji, która wydaje się błaha (ale sa na ten temat 4 depesze, umieszczone jedna pod druga), a ponadto nieprawdopodobna, jak przyznaje to sama redakcja dziennika? Być może, umieszcza się ją tutaj, by skwitować wszystko piątą depesza, zawierająca potwierdzona wiadomość, „że prowadzą się układy z Berlinem o ułatwienia w stosunkach pogranicznych francusko-niemieckich". W tym samym dziale znajdują się jeszcze: informacje z Londynu (o wyborze Polydore'a de Keysera na Lorda Mayora i o pożarach 
w Ameryce), z Sofii (o bułgarskim projekcie zaciągnięcia pożyczki u księcia Coburga), z Rzymu (cholera w Mesynie), z Petersburga (na samym końcu, na dole stronicy - o Radzie Państwa debatującej nad ustawami dla przedsiębiorców oraz o urlopie ambasadora niemieckiego, generała Schweinitza). Po pierwsze, waga tych informacji wydaje się bardzo nierównomierna (francusko-niemieckie zatargi graniczne i urlop niemieckiego ambasadora). Po drugie - część wiadomości zostaje powtórzona, a nie zsyntetyzowana (cztery szczegółowe telegramy o bójce między żołnierzami). Po trzecie - nowoczesne medium, jak się okazuje, nie czyni rzeczy całkiem pewnymi i sama redakcja opatruje ostrożnym komentarzem („nieprawdopodobne”) to, co zostało przesłane ,ze świata”. Po czwarte - nie jest jasne, jaka była zasada klasyfikowania informacji: oparta na sposobie ich przekazywania (,telegramy" - jako oddzielny typ wiadomości, szczególnie aktualnych) czy na tematyce. W niektórych numerach ten sam dział nazywa się Ze świata i $Z$ Cesarstwa, w niektórych Wiadomości bieżace, w niektórych zaś pojawiaja się wszystkie te tytuły. Sąsiadują ze sobą informacje o najróżniejszym charakterze. W Wiadomościach bieżacych to np.: operacje rosyjskiego ministerstwa finansów i rosyjskie pożyczki zagraniczne, działalność towarzystw asekuracyjnych, planowana liberalizacja „wydawania przywilejów na wynalazki”, o której piszą dzienniki petersburskie, a „Kurier" to przedrukowuje; prace ministerstwa komunikacji i dróg wodnych, pomysł inżynierów francuskich, by przeprowadzić sieć kanałów łączących Bałtyk z Morzem Czarnym - donoszą o tym nieokreślone „dzienniki zagraniczne”; działania ministerstwa spraw wewnętrznych w sprawach koniokradztwa, zjazd chmielarzy, piwowarów, rolników i młynarzy oraz spotkanie kwartalne członków archikonfraterni literackiej, które ma się odbyć w Warszawie ,jutro”; losowanie akcji i obligacji Towarzystwa Drogi Żelaznej Warszawsko-Terespolskiej i rozpoczęcie wypłat obligacji pożyczki I i II serii m.st. Warszawy zaciągniętej na urządzenie kanalizacji i wodociagów. Sekcja Ze świata zawiera m.in. takie tytuły: Wystawa pszczelnicza w Poznaniu, Wycieczka Czechów do Krakowa, ponadto dalsze doniesienia dotyczące burmistrza Pragi, instalowania linii telefonicznej łączącej Wiedeń z Pesztem oraz zjazdu lekarskiego w Waszyngtonie.

W latach osiemdziesiątych XIX w. stosuje się wciąż sztywną makietę. Układ strony „Kuriera” jest trójkolumnowy, informacje umieszczone w poszczególnych działach „przelewają się” między kolumnami - trzy ostatnie linijki Wiadomości bieżacych znajduja się np. tuż nad Nekrologia, ta zaś płynnie przechodzi w Dział Przemysłowo-Handlowy. Zawiadomienie o tym, iż „Pogrążeni w smutku żona i synowie zapraszają krewnych, przyjaciół i znajomych na wyprowadzenie zwłok", sąsiaduje $z$ danymi o cenach zboża na światowych giełdach i o kursach walut. Informacje o otwarciu nowych połączeń kolejowych - $\mathrm{z}$ wiadomością o tym, że włościanin $z$ Wilanowa przejechał innego włościanina konnym wozem, ta zaś z doniesieniem o samobójstwie, które popełnił jakiś nieszczęśliwy młodzieniec, zjadając fosfor $\mathrm{z}$ zapałek. Bieżące informacje warszawskie mają podobną rozpiętość: tematem regularnie podejmowanym przez redakcje „Kuriera” jest modernizacja miasta, której najczęściej wspominany przejaw stanowią rozmaite utrudnienia w życiu codziennym warszawiaków (budowa kolejnych odcinków wodociagów, pęknięcia istniejących rur wodociagowych i zapadnięcie się fragmentu ulicy, kłopoty z komunikacją tramwajową). Pisze się o nowym oświetleniu gazowym, o problemach hi- 
gienicznych, o stanie szpitali warszawskich. Drukuje się skorowidz adresowy przyjezdnych zameldowanych w warszawskich hotelach, wykaz listów i depesz, których nie udało się doręczyć, co oznacza, że dziennik był „ostatnią instancją informacji”, działająca skuteczniej niż system pocztowy czy system połączeń telefonicznych (ten pierwszy - w stanie dużej dezintegracji, ten drugi - dopiero w początkowej fazie rozwoju).

W nie mniej interesujący zbiór tematów i form układają się reklamy oraz ogłoszenia drobne $z$ „Kuriera”. Atrakcje takie, jak „Nadzwyczajny cud natury: 3 i pół łokcia wysokości, 230 funtów, lat 11 (dowody prawne)” oraz „Piękna Galatea - biust marmurowy ożywający wobec widzów; nowość sprawiająca wielkie wrażenie w całej Europie”, prezentowane w przybytku o nazwie „Muzeum Bozwa” czy też zaproszenie na pokazy fajerwerków $w$ klatce $z$ lwami sąsiadują $z$ ogłoszeniem warszawskiego przedsiębiorcy zajmującego się osuszaniem budynków, który jako gwarancję jakości swych usług podaje Nagrodę Postępu: srebrny medal zdobyty na wystawie w Brukseli w 1888 roku. Anons „mamki ze świeżym pokarmem” poszukującej posady („wiadomość u stróża przy ulicy Hożej”) umieszczono w niedalekim sąsiedztwie reklamy sztucznego mleka dla niemowląt firmy Henriego Nestlé. Nie wiem zreszta, które $\mathrm{z}$ tych akurat ogłoszeń mówi o większej zmianie: czy to zapowiadające szybkie nadejście epoki żywności instant, czy to rekomendujące „mamke”, należąca, jak mogłoby się wydawać, do porządku raczej pozapiśmiennego, znajdującą się gdzieś blisko natury, niemal czystej fizjologii, tu zaś stającą się świadomą obiegu informacji usługodawczynią, która formułuje ogłoszenie, opłaca je i - sama czy też z czyjąś pomoca - umieszcza w popularnym dzienniku.

To bardzo krótki przegląd zawartości „Kuriera Codziennego” (jakkolwiek - jest to lektura pasjonująca!). Pomieszanie rzeczy błahych i istotnych, niemożność oceny, co stanowi wiedzę, a co dziwactwo czy nawet szaleństwo, co należy do porządku informacji, a co jest sensacją; pomieszanie gatunków - poetyka tekstów w tym warszawskim dzienniku waha się pomiędzy „newsem”, przypowieścią, kazaniem, przemowa, anegdotą, odczytem, wykładem. Wiadomość o promieniach Roentgena dociera do warszawskich czytelników za pomoca obszernej, tekstowej reklamy cudownych „cukierków norwegskich”, które - podobnie jak elektryczna maszyna Herculesa Sanche’a - leczą wszystkie choroby. Możliwość zobaczenia „ciała ludzkiego w stanie przejrzystym" (to tytuł artykułu reklamowego) przynosi dowody na skuteczność norweskich pastylek; widać, jak zdrowieje ciało prześwietlone promieniami X. „Naukowo potwierdzony” jest wiek karła wystawianego w goszczacym w Warszawie „Muzeum Bozwa” - czyli połączeniu ludzkiej menażerii, fotoplastikonu i muzeum anatomicznego. W obrazie świata kreślonym przez XIX-wieczne dzienniki wynalazek znajduje się blisko iluzjonistycznej sztuczki, odkrycie - w sąsiedztwie objawienia, „dowód prawny” dodaje wiarygodności cyrkowym pokazom. Elektryczność nie jest bardziej widoczna od ektoplazmy, pomysł prześwietlania ludzkiego ciała czy też informację o pierwiastkach promieniotwórczych można traktować $z$ równym entuzjazmem, jak wiadomość o pracach nad wynalezieniem metalu lżejszego od powietrza, a Kongres Spirytystów w Paryżu może wydawać się przedsięwzięciem nie mniej rozsądnym od zjazdu Międzynarodowego Związku Telegraficznego.

To właśnie świat bohaterów i czytelników Prusa. Rzeczywiste zmiany następo- 
wały w swoim tempie, było ono jednak dużo wolniejsze od szybkości doniesień prasowych. Pierwsza scena Lalki wydaje mi się trafnym obrazem takiego właśnie doświadczania postępu zapośredniczonego przez prasę. Powieść Prusa zaczyna się przecież od dyskusji „o świecie i o mieście”:

Zatopieni w kłębach dymu cygar i pochyleni nad butelkami z ciemnego szkła, obywatele tej dzielnicy jedni zakładali się o wygranę lub przegranę Anglii, drudzy o bankructwo Wokulskiego; jedni nazywali geniuszem Bismarcka, drudzy - awanturnikiem Wokulskiego; jedni krytykowali postępowanie prezydenta MacMahona, inni twierdzili, że Wokulski jest zdecydowanym wariatem, jeżeli nie czymś gorszym... [L-1 4-5] $]^{17}$

Miejska renomowana jadłodajnia, mikroświat pochylonych nad talerzami i kuflami mężczyzn, posiadaczy kamienic, bez zajęcia, fabrykantów i ojców rodzin, powtarzających sobie bardzo ważne rzeczy bez znaczenia, zaczerpnięte $z$ prasy wiadomości okraszane „życiową mądrościa”, która każe sądzić to lub zgoła co innego. Otwierający powieść obraz miasta to świat zamknięty, podziemny niemal, bez okien, bez widoku na zewnątrz, nieruchomy. Ruchliwy jest tylko świat redakcyjny - stuka telegraf, terkoce maszyna rotacyjna. Reszta miasta czasów postępu pogrążona jest w całkowitym marazmie. To nie biegnacy w swoich sprawach przedsiębiorczy mieszkańcy metropolii są bohaterami Prusa. To czytelnicy prasy, o umysłach sformatowanych w trzy kolumny, w których wiadomość o tym, że pani Minclowa czegoś się najadła czy też czymś się wysmarowała, że ktoś otwiera nowy sklep, łączy się płynnie $z$ doniesieniami o światowych konfliktach i zawartych pokojach. Wszystko ma taką samą wagę - zadrukowana stronica jest nad wyraz demokratyczna.

Watpliwe wydaje się to, że dla autora Emancypantek wszystkie te cudowności, wynalazki, odkrycia, osiagnięcia, o których się w tamtym stuleciu nieustannie mówiło, były równoznaczne $z$ impulsami rzeczywistej i głębokiej zmiany. Nie jest też całkiem jasne to, czy można podtrzymywać entuzjastyczną tezę o związku między postępem cywilizacyjnym (czyli - w języku Prusa - tym, który łączy się z rozwojem nauk, techniki, gospodarki) i doskonałością moralną. Przywołam tutaj jeszcze jeden późny felieton Prusa: Miasto zahipnotyzowane z 1909 roku. To świadectwo głębokiego rozczarowania - Warszawa została ucywilizowana, wyposażona w nowoczesne oświetlenie gazowe i takiż system wodociagów, poszerzono ulice, wyrównano chodniki, po mieście można poruszać się tramwajami. Wszystko się zgadza, prócz związku między postępem cywilizacyjnym a moralnym - konstatuje Prus. Miasto jest pozbawione życia, pogrążone we śnie-hipnozie, oddalone od siebie samego, uważane przez mieszkańców za przestrzeń obcą. Tak jak gdyby mimo wprowadzenia rozmaitych udoskonaleń na dużą przecież skalę, mimo znacznych zmian w urządzeniu życia codziennego - Warszawa pozostawała w bezruchu i nie nabrała nigdy tempa metropolii. Proces modernizacji widziany $z$ tej perspektywy zaczyna być dość podejrzany, ponieważ może wydawać się częścią systemu opresji. Do dotkliwości związanej z sytuacją polityczną dołącza się „postęp” - jako proces

17 W ten sposób odsyłam do: B. Pr u s, Lalka. Oprac. J. B a c hó r z. T. 1-2. Wrocław 1991. BN I 262. Pierwsza liczba po skrócie, po łączniku, oznacza tom, następna - stronicę. 
obcy, wymuszany, niechciany. Prawdę powiedziawszy - dziwne to uczucie zobaczyć Prusa po stronie krytyków nowoczesności; a nawet jeśli nie jest to strona krytyków, to jest to strona wątpiących zarówno w wartość oraz znaczenie zmian cywilizacyjnych, które dokonywały się na ziemiach polskich w ostatnich dekadach w. XIX, jak i w wartość samej idei postępu.

Pytanie, jaka zachodzi relacja między pojęciami społeczeństwa polskiego i postępu, stanowi jedno $\mathrm{z}$ najważniejszych pytań organizujących myśl tego autora. Jest to - jak już sygnalizowałam - relacja złożona i niejednoznaczna. Mamy u Prusa - sądzę - co najmniej dwie różne kwestie i co najmniej dwa sposoby opowiadania o tej relacji.

Pierwsza kwestia to przeświadczenie o straconej polskiej szansie. W przywoływanym tu wcześniej odczycie $z$ lat siedemdziesiątych ( $O$ odkryciach i wynalazkach) mamy sygnał czyhającego na mieszkańców Kongresówki zagrożenia stoczeniem się na stronę „dzikości”: chodzi przecież o tych, którzy nic nie rozumiejąc ze współczesnego świata, mogą w najlepszym razie zostać skolonizowani, w najgorszym - bez śladu zniknąć $z$ powierzchni ziemi. W późnych wypowiedziach Prusa brak tonu wątpliwości i wiele wskazuje na to, że sprawa uczestnictwa Polaków w dziejach postępu rozstrzygnęła się na ich niekorzyść. Ludzkość znajduje się gdzie indziej, my zostaliśmy po drugiej stronie:

Barbarzyńca nie potrafi zbudować maszyny parowej, młocarni, siewnika, armaty, okrętu. Co najwyżej - na widok tych cudownych przedmiotów może „wpaść w natchnienie” i wypowiedzieć poemat ewentualnie bardzo malowniczy, bardzo piękny. Toteż ludy barbarzyńskie, nieliczne, źle zabezpieczone od głodu, chorób i ucywilizowanych nieprzyjaciół nie tylko usuwają się przed nimi ze swoich terytoriów, ale wprost gina, wymierają, pomimo że nieobca jest im ornamentyka, wymowa i poezja!... ${ }^{18}$

W roku 1909 jest już dla Prusa całkiem jasne, że te ludy barbarzyńskie nie zamieszkują lasów tropikalnych, lecz równiny mazowieckie:

A my?... Czymże jest nasze stanowisko wśród ludów?... Na widok rzeczy nowej umiemy się ucieszyć, podziwiać ją, przestraszyć, a nawet opowiedzieć o niej wierszem lub prozą i... na tym koniec... Sił mechanicznych, cieplikowych, elektrycznych, chemicznych posiadamy niezbyt wiele, posługujemy się nimi w granicach dosyć skromnych; nowych machin i motorów nie budujemy sami, lecz sprowadzamy je zza granicy, o wynalazkach naszych jakoś... nic nie słychać... Czymże więc jesteśmy w cywilizacji?... Jaka mamy pewność dalszego rozwoju, a nawet - jaką pewność dłuższego istnienia? - A wszystko dzięki temu, że posiadając niemało umysłów literackich, artystycznych i poetyckich, liczymy między sobą niesłychanie... niesłychanie mało ludzi z umysłowością naukową, wykształconych na fizyce i chemii... ${ }^{19}$

Kwestia druga jest jednak związana ze sprawą inną niż ówczesne położenie Polaków i łączy się z zagadnieniem odmiennym od problemu relacji „polskości wobec ludzkości” czy problemu polskiego uczestnictwa (lub raczej jego braku) w procesie modernizacyjnym toczacym się w społeczeństwach Europy Zachodniej. Industrializacja, koncentracja ośrodków miejskich, rozwój techniczny i upowszechnienie, dostępność jego rezultatów, procesy emancypacyjne dotyczące grup oraz stanów społecznych do tej pory wykluczonych $z$ dominującego dyskursu, narodzi- 
ny i rozwój burżuazji - wszystkie te kwestie Prus porusza w swoim dziennikarstwie, a niektóre znajdują także swój wyraz literacki. Ostateczna konstatacja pisarza wydaje się jednoznaczna; nie była ona stwierdzeniem doraźnym, wygłoszonym w chwili niepokoju, czy wypowiedzianym tak wyraziście dla wymogów retoryki. Diagnoza ,jesteśmy po stronie barbarzyństwa” zostaje sformułowana po niemal czterech dekadach nadzwyczaj systematycznej obserwacji polskiego życia codziennego i śledzenia rozmaitych tego życia przejawów. Prus napisał znacznie ponad 1000 felietonów, które układają się w swoisty, drobiazgowy „dziennik życia polskiego" - „Czy nas zbawią balony i czy nas uświęca samoświecace guziki”?20 Pytanie jest retoryczne, wiadomo, że ani nie zbawią, ani nie uświęcą.

Gdyby dziś zmartwychwstał Homer i ujrzał nasze cygarniczki z bursztynu, flaszki ze szkła, poszewki z tyryjskiej purpury, rzekłby: „To jest ojczyzna królów!” Ale gdyby zobaczył, że siedząc w Warszawie możemy wiedzieć, co w tej chwili dzieje się w Paryżu, gdyby mu pokazano lokomotywy naszych pociagów, pociski artylerii, elektryczne klejnoty baletnic i pienistego szampana, upadłby na twarz i zawołał: „Kraj wasz jest Olimpem, napój nektarem, a wy bogami, którzy jeżdżą na smokach i noszą gwiaździste szaty. O, jak muszą być potężne wasze rozumy i wielkie serca; jak jesteście szczęśliwi!”

Dopiero kilkuletni pobyt nauczyłby go, że pod pokostem niezmiernych ulepszeń technicznych kłębi się odwieczna chciwość i oszustwo, słabość i głupota, ból i narzekanie; słowem - stary człowiek, który przez trzydzieści wieków nie zmienił się ani na jotę.

Skąd brać mamy naukę, że dziś pilniejszą rzeczą jest udoskonalić ludzką duszę aniżeli sposób kierowania balonami, a nawet - samoświecące guziki ${ }^{21}$.

Pożary w Siedlcach i zbiórki dla pogorzelców, którzy z uporem odbudowują się „na drewniano”. Szkoły dla rzemieślników. Opłakane położenie tychże. Brak instytucji edukacyjnych. Zapóźnienie wobec postępu technicznego i naukowego na Zachodzie. Brak szacunku dla rodzimych talentów, umiejętności i osiagnięć. To są zagadnienia, które przez 40 lat pojawiają się w felietonistyce Prusa niczym refreny tego „dziennika życia polskiego” czy może raczej „dziennika marzenia o zmianie”; lektura tego wszystkiego prowadzi do prostego spostrzeżenia: owe zagadnienia sa centrami uwagi autora, osiami tematycznymi organizującymi całość potężnego cyklu.

Wszystkie te kwestie są ważne. Czy jest jednak tak, jak skłonni bylibyśmy sądzić biorąc za dobrą monetę pozytywistyczne nadzieje wobec rozwoju sztuk i nauk? Czy jeśli trudności zostaną przezwyciężone, idea postępu przyjęta i zastosowana, szkoły dla rzemieślników otwarte i dostępne, rodzimi uczeni i wynalazcy docenieni, a ich osiagnięcia wdrożone - staniemy się społeczeństwem (niemal całkowicie) szczęśliwym? Lektura felietonów Prusa dostarcza tu sprzecznych wrażeń, odpowiedź na to pytanie jest jednocześnie twierdząca i przecząca.

Wydaje się bowiem, że od samego początku w pisarstwie Prusa dotyczącym dobrodziejstw postępu - obok nuty przeświadczenia (tak charakterystycznego dla epoki) o nieuchronnym szczęściu, które stanie się udziałem ludzi dzięki maszynie parowej, kolei, telegrafowi i nowym sposobom komunikacji oraz dzięki innym odkryciom i wynalazkom - pobrzmiewa niekiedy ton lęku, niepewności. Tak jakby nadchodzący lepszy świat był jedynym spośród potencjalnych światów, a związane 
z nim zmiany - nieuniknione, jednak wszystko to razem niemożliwe do przyjęcia i przeżycia, obce, niejasne. Nawet jeśli czymś, przed czym nie ma ucieczki, jest powszechne szczęście - niewesoła to perspektywa.

Wracam tutaj do snu-felietonu Prusa o kryształowym pałacu, pełnym ludzi żyących w dostatku i nieustannym zagrożeniu upadkiem. Obraz ten przypomina inną wizję społeczeństwa postępu - Panoptikon Jeremy’ego Benthama. Jeśli przejrzysty pałac ze snu jest metaforą nowoczesnego społeczeństwa, społeczeństwa postępu, to jest ono pod wieloma względami bardzo podobne do „społeczeństwa dyscyplinarnego", którego model Michel Foucault wyprowadza z praktycznych zaleceń Benthama. Życie w pałacu postępu, życie „w wystawie” / „na wystawie” oznacza zgodę na wszechwładzę oglądalności i na nieuchronność bycia oglądanym. Władza spojrzenia jest dystrybuowana sprawiedliwie - każdy posiada jej część, jednak każdy z członków społeczeństwa wystawy także jej podlega. „Spojrzenie ustanawiające tożsamość”, oglądanie i bycie oglądanym to ważne bardzo praktyki społeczeństwa XIX-wiecznego. O tej „Zwykłości władzy”, o tym, że jest ona rozproszona, nie związana w gruncie rzeczy z instytucją i należnym jej ceremoniałem, majestatem władzy - pisze Foucault ${ }^{22}$. Do wnętrza szklanej wieży Panoptikonu, do której wchodzi się po to, by oglądać i kontrolować, samemu przez chwilę nie będąc widzianym, ma wstęp każdy. Społeczeństwo panoptyczne, dyscyplinarne społeczeństwo „wzajemnych oględzin" jest więc głęboko demokratyczne - w najstraszniejszym jakimś sensie tego słowa: wszyscy kontrolują, ale też wszyscy podlegają kontroli. Są oglądani, choć nie wiedzą, kiedy i czy w ogóle; narzędziem porządkujacym staje się obserwacja potencjalna, niekoniecznie rzeczywiście mająca miejsce. Wystawa jest bardziej jeszcze dyscyplinująca: brak tu wieży, do której można się oddalić i pozostawać w niej poza władzą spojrzeń. Przeszklona galeria dobrobytu jest przestrzenią absolutnej przejrzystości; nie ma od niej ucieczki.

Warto przypomnieć tutaj rozpoznanie Richarda Sennetta: jednym z najważniejszych mechanizmów regulujących zachowania członków XIX-wiecznego miejskiego społeczeństwa burżuazyjnego jest lęk przed mimowolną, nieintencjonalną komunikacją. Ulica oraz inne miejsca publiczne, takie jak teatr, sklep, kościół, park, stają się możliwymi przestrzeniami bezwiednej ekspresji - zarazem zaś wzmaga się lęk właśnie przed bezwiedną ekspresją. To ten lęk determinuje wiele postaw i zachowań, ta właśnie obawa, by nie ujawnić czegoś, czego się okazywać nie zamierza lub nie powinno. A jednocześnie autentyczność stanowi ważne i wysoko cenione kryterium udanego życia ${ }^{23}$.

Jeśli przyjrzeć się z tej perspektywy bohaterom Lalki, to ich skrępowanie obawa przed mimowolną ekspresja jest bardzo wyraźne. Owo doświadczenie ma swoje ekstensje - obawą taką zostają naznaczone przestrzenie publiczne i prywatne.

Niezbyt zręcznie jest pisać o powszechnie znanej powieści, przypomnę jednak kilka obrazów: pokój Rzeckiego, w którym kolory są nieokreślone - firanka może

M. F o u ca ult, Nadzorować i karać. Narodziny więzienia. Przeł. T. Ko men d a n t. Warszawa 2009.

23 R. S e n n ett, Upadek człowieka publicznego. Przeł. H. J a n k ow s k a. Warszawa 2009, zwłaszcza cz. 3: Dezorganizacja życia publicznego w XIX wieku. 
kiedyś była zielona, ale wypłowiała, a czarny stół, czarna piaseczniczka i ciemnowiśniowe sukno niewiele mówią o właścicielu, trudno je uznać za rzeczy o s o b i s te. Uśmiech na twarzy Kleina jest p o s in i a ły, Mraczewski przemieszcza się w s m ud ze woni, Lisiecki ma os zr o ni on e wąsy. To nie są ekspozycje bohaterów - poruszają się oni w jakimś paśmie sensualnej nieokreśloności. Jan Mincel miał podobno rumiana twarz i siwe wassy - jak dowiadujemy się od starego subiekta. Jednak wszyscy starsi mężczyźni w Lalce cechują się siwizną i rumianymi twarzami i Mincel umieszczony w jakimkolwiek miejskim zgromadzeniu ukryłby się przed nami - dzięki swej typowości.

O Izabeli wiemy jakby więcej:

Wszystko w niej było oryginalne i doskonałe. Wzrost więcej niż średni, bardzo kształtna figura, bujne włosy blond $\mathrm{z}$ odcieniem popielatym, nosek prosty, usta trochę odchylone, zęby perłowe, ręce i stopy modelowe. Szczególne wrażenie robiły jej oczy, niekiedy ciemne i rozmarzone, niekiedy pełne iskier wesołości, czasem jasnoniebieskie i zimne jak lód. [L-1 79]

Zwracam uwagę na użycie określenia „oryginalne” w tym opisie, który jest najzupełniej typowy i każe nam sądzić, że poza „wyjątkowa pięknością” w Izabeli nic wyjątkowego nie było. „Oryginalność” więc przeciwstawiona zostaje nie „typowości”, ale - „podróbce”. Izabela jest oryginalna jak markowy produkt. W latach osiemdziesiatych XIX w. kwestia oryginalności znaku towarowego była już bardzo istotna, pojawia się ona nawet w reklamach umieszczanych w warszawskich gazetach codziennych w tym okresie. Agenci sprowadzający do Królestwa Kongresowego amerykańskie wyżymaczki Empire czy sztuczne mleko dla niemowląt firmy Nestlé ostrzegają przed podróbkami i zapewniają o niezawodności i doskonałej jakości tylko oryginalnych produktów. Pojawiają się doniesienia o oszustwach: np. „Kurier Codzienny” 23 III (4 IV) 1899 pisał o fałszywych metkach „mode de Paris”. Jak się okazało w wyniku dziennikarskiego śledztwa - przedmioty toaletowe i galanteryjne oznaczone tą marką sprowadzane były przez kupców warszawskich dla taniości $z$ Berlina, nie $z$ żadnego Paryża. W tej dobie sens pojęcia oryginalności zostaje zwiazany na dobre ze znakiem towarowym.

W mieście Lalki drzewa są czarne, trawniki szare i niebo szare; taki jest krajobraz tuż przed Wielkanocą, taki sam sąd o zewnętrznym świecie półświadomie formułuje Izabela, nie wyglądając nawet za okno. Zewnętrzna szarość, która stanowi bardziej założenie niż spostrzeżenie, zmienia kolor wnętrza pokoju, kolor oczu i szlafroczka: wszystko błękitne - szarzeje. O samym Wokulskim wiemy jedynie, że jego ręce wydawały się Izabeli rażąco czerwone. To tyle. Niewiele. Wystarczająco.

Człowiek pisma, człowiek nowoczesnej powieści nie musi już niczego nazywać. Precyzja Mickiewicza, konkret nazw i oznaczeń - nazwy miejscowe, nazwy sprzętów i roślin czy botaniczne szaleństwo nazewnicze Orzeszkowej należą do innego świata, podobnie jak katalogi sprzętów u Reymonta. Słowo Lalki przestaje być substancjalne, opowieść nie musi już stwarzać świata. Nie jest jej zadaniem uobecnianie doświadczenia zmysłowego. Nieodmiennie mnie dziwi, że Prusa nazywa się autorem „realistycznym”. Nie jestem w stanie trafnie określić tego, na czym miałby polegać realizm jego powieści, która w części wydaje się „przepisywaniem” świadectw wizualnych epoki, w części narracja właściwą prasie, w części - dowodem niemożności uchwycenia rzeczywistości w jakimkolwiek jej sensie: zewnętrznej, wewnętrznej, 
sensualnej, duchowej, psychologicznej. Jedyne, co możliwe, to spojrzenie; ono zaś, po pierwsze, jest omylne i daje się zwodzić najrozmaitszymi sztukami; po drugie - wszyscy prowadza panoptyczna grę ucieczki przed spojrzeniem.

Gdy Wokulski wędruje na Powiśle - spostrzega „parterowe i jednopiętrowe domki barwy czekoladowej i jasnożółtej, ciemnozielonej i pomarańczowej. Nic, oprócz białych i czarnych parkanów, otaczających puste place, skąd gdzieniegdzie wyskakuje kilkupiętrowa kamienica [...]" (L-1 136-137). Wokulski widzi raczej kompozycję kolorów charakterystyczną dla palety Gierymskiego, o którym wiadomo, że był dla Prusa malarzem bardzo ważnym.

Wracam tedy znowu na Wystawę Sztuk Pięknych, po raz szósty oglądam obraz i przekonywam się, że - posiada on coś więcej niż to, co zwykłe oko dopatrzy w naturze. Posiada - geniusz artysty, który przegląda z każdej łódki, tratwy, berlinki, z każdego chałata, z nieba, z ziemi i z wody

- pisze Prus w felietonie poświęconym polemice z krytykami obrazu Gierymskiego Żydzi modlacy się nad Wisłą $w$ dzień święta Trąbek ${ }^{24}$.

W innym miejscu Lalki czytamy o tym, że „Warszawa posiada bardzo wiele żółtych domów; jest to chyba najżółciejsze miasto pod słońcem" (L-1 323), a szczególnie żółta jest kamienica Łęckiego: otrzymałaby ona $\mathrm{z}$ całą pewnością pierwszą nagrodę na wystawie przedmiotów żółtych (która, jak stwierdza się w powieści, niewątpliwie się kiedyś odbędzie) - kolejny mały dowód na to, że Prus patrzył na Warszawę swoich bohaterów przez „pryzmat ówczesnych nośników wizualności”. Oczywiście, to jest kolor „przymusowy” w Warszawie drugiej połowy XIX stulecia. Jednak może i tutaj udałoby się wskazać na inne odniesienia. Np. ze szkiców i akwareli Zygmunta Vogla wynika, że cały świat jest żółty (nie tylko Warszawa, ale i Kock, Kraków czy Kazimierz). Niewykluczone, że Prus pisząc o Warszawie miał przed oczami akwarele, obrazy, fotografie i pocztówki; gdy zaś wyglądał przez okno, patrzył - podobnie jak jego bohaterowie - raczej na cienie i przepływające obłoki. Olśniewające jest - jak wyznaje - to, że Gierymski nie „przedstawia rzeczy”, ale maluje światło. To ono wydobywa $z$ rzeczy istotę (prawdę?), świat istnieje tylko w oświetleniu. Autor Lalki zwierza się w felietonie, że udał się na Powiśle i przyglądał się domom, łódkom, rzece. Wszystko to jednak nie było tym, czym jest na obrazie Gierymskiego; naiwne może wydawać się żądanie od rzeczywistości, by okazała się obrazem. Od rzeczywistości należałoby raczej oczekiwać, że pozwoli się w jakikolwiek sposób doświadczać. I chyba z rozmaitych sądów Prusa da się wywieść wniosek, że jest to niemożliwe. Możliwe jest jedynie doświadczanie rzeczywistości utrwalonej, gdyż ona - dzięki medialnemu zapośredniczeniu - oświetla rzeczy we właściwy sposób.

Przypuszczalnie nie chodzi tylko o doświadczenia wizualne. Wszystkie doświadczenia sensualne bohaterów Prusa są ubogie - swiat Lalki i pozostałych jego powieści ma niewiele zapachów, dźwięków i faktur. Krótkie i raptowne wycieczki w stronę innych autorów zwykle nie są dobrym pomysłem, przyjrzyjmy się jednak pierwszemu zdaniu powieści Émile’a Zoli Brzuch Paryża (1873):

Opustoszałą aleją i wśród wielkiej ciszy wozy jarzyniarzy ciągnęły pod górę w stronę Paryża, z ryt- 
micznym turkotem kół, który odbijał się echem od fasad domów, śpiących głęboko z obu stron drogi, za mglistymi rzędami brzostów ${ }^{25}$.

Całkowita cisza uśpionego miasta, w którą wdziera się rytmiczny turkot wjeżdżających do niego wozów; początek akcji, impuls poruszający wzrok i słuch, kadr inicjujący „dzianie się”. Brzuch Paryża, podobnie jak Wszystko dla pań można traktować jako sprawdzian siły słowa, jako eksperyment - czy literatura jest w stanie zastąpić wszelkie sztuki istniejące (malarstwo i fotografia), przyszłe (film), oraz nieistniejące, ale możliwe (czyli takie, które bezpośrednio pobudzałyby zmysł węchu i dotyku).

Co naprawdę ogarnia spojrzenie bohaterów Prusa? Na czym polega kontrola spojrzeń, skoro bohaterowie Lalki tak skutecznie przed nią uciekają? Według autora prawda leży po stronie fotografii i jego stanowisko jest tutaj całkowicie jednoznaczne. W końcówce lat osiemdziesiątych XIX w. temat ten dość często pojawia się w pisarstwie Prusa. W felietonie Przyszła rola fotografii $w$ rzeczach dotyczacych moralności znajdujemy zapowiedź przyszłości, w której świat stanie się doskonały dzięki powszechnemu użyciu wynalazku Daguerre’a. Wszyscy wyposażeni będą w mikroaparaty fotograficzne, „zdejmujące” każdego przestępcę na gorącym uczynku.

Słowem, gdziekolwiek ruszysz się, czegokolwiek dotkniesz, kogo zaczepisz, wszędzie spotkasz się z aparatem fotografującym cię w kilkunastu pozach. Każdy cal ściany, sufitu i podłogi, każdy sprzęt, każda część ubioru publicznie i bez litości oskarżą cię o wszystkie grzechy śmiertelne i powszednie, własne i cudze ${ }^{26}$.

System powszechnego fotografowania ułatwi pracę sądom, uwiarygodni i przyspieszy wydawanie wyroków:

Podobne warunki mogą wytworzyć nie znane dziś specjalności. I nie w jednym domu na liście lokatora czytać np. będziemy: Numer lokalu: 23. Imię i nazwisko lokatora: Fabian Drygalski. Z czego się utrzymuje? Z nagród za cnotę ${ }^{27}$.

W czasach pracy nad Lalka fotografia była już dobrze znana, a Prus uważał ją za jedno z najwspanialszych i najbardziej znaczących osiągnięć XIX wieku. Nawet jeśli potraktować felieton o systemie „powszechnej kontroli fotograficznej” jako rodzaj przewrotnego żartu, nie można pominąc innych wypowiedzi na ten sam temat. Szczególnie entuzjastycznie Prus odnosił się do tzw. fotografii momentalnej:

Właśnie kiedy byłem na onegdajszym koncercie symfonicznym, przyszedł mi na myśl Szopen Siemiradzkiego i Wernyhora Matejki. W Szopenie panuje taka cisza, jakby koncert odbywał się na fortepianie bez strun; w Wernyhorze jest taka burza, jakby lirnik zamiast liry trzymał w ręku machinę elektryczną największego kalibru.

- Który ma rację? - pytałem się patrząc na słuchaczów symfonii.

I widziałem fizjognomie: wesołe, smutne, zaciekawione, apatyczne, rozmarzone, zajęte czym innym, ale - żadnej tak spokojnej jak u Siemiradzkiego, ani tak wzburzonej jak u Matejki.

- Ot - myślę - gdyby tu postawić Brandla $z$ jego szybkostrzelnym aparatem fotograficznym... dopieroż by malarze mieli dokument: w jaki sposób ludzie słuchają koncertu!...

É. Zo la, Brzuch Paryża. Przeł. N. Gu bry n ow i cz. Warszawa 1957, s. 5.

Pr u s, Kroniki, t. 10 (1960), s. 122. (Pierwodruk: „Kurier Codzienny” 1887, nr 133, z 15 V).

Ibidem, s. 123. 
I jeszcze bardziej wzmocnił się mój szacunek dla fotografii momentalnej, w której urzędowa krytyka już upatruje grób sztuki ${ }^{28}$.

Autor rozwija w felietonie ten początkowy obraz i zmierza ku następującej konkluzji: fotografia jest kolebką nowych postępów w sztukach pięknych. Nie dlatego bynajmniej, że mogłaby zwalniać malarstwo z obowiązku mimetyczności. Wręcz odwrotnie - momentalne fotografie „bitew, egzekucji, koncertów na lirze i na fortepianie” doprowadziłyby malarzy do przedstawiania prawdy, „Matejko nie byłby tak gwałtownym, Siemiradzki tak spokojnym w swoich kompozycjach [...]"29.

W innym felietonie $z$ tego samego czasu, Wyprawa Sabowskiego przeciw fotografii momentalnej, Prus podkreśla pożytki, jakie fotografia może przynieść malarstwu i rysownictwu - właśnie przez to, że, w jego opinii, jest ona „prawdziwa” i dostarcza wiarygodnych szkiców $z$ natury. Pozwala więc malarzowi na ominięcie długiego i pracochłonnego procesu wykonywania „studiów do...”, zwalnia go też z konieczności polegania na własnym oku, które jest zawodne, zwłaszcza przy obserwacji ruchu:

za prawdziwość każdej fizjognomii, każdego ruchu ręki, nogi, odzienia - pan Brandel może ręczyć głową. Gdyż zrobiła to „bezmyślna maszyna...”

Krótko mówiąc: dla „obserwacji malarskiej”, dla notowania postawy, fizjonomii i wszelkiego ruchu fotografia momentalna jest tysiąc razy lepszą szkołą aniżeli wszelkie wzory klasyczne. Jest jeszcze tysiąc razy pewniejsza aniżeli oko malarza; jest tym dla artystycznych notatek, czym telegraf dla komunikacji ${ }^{30}$.

W okresie, w którym toczy się akcja Lalki, w Warszawie funkcjonowały już zakłady fotograficzne. Zakład słynnego Konrada Brandla od 1865 r. mieścił się przy ulicy Nowy Świat 57, zatem bardzo blisko głównych miejsc akcji powieści. Wcześniej istniał choćby zakład Beyera, nauczyciela Brandla. Od roku 1866 Brandel wydawał bardzo popularne fotograficzne ścienne kalendarze warszawskie - kunsztowne fotomontaże, które stanowić miały panoramę najważniejszych wydarzeń roku. Całość reprodukowana była najnowszą wtedy metodą światłodruku. Na kalendarz składały się studia architektury, pejzaże, widoki miasta, a więc przede wszystkim fotografia statyczna. Ale zdarzały się i prekursorskie zdjęcia „reporterskie” miejskie sceny rodzajowe i obyczajowe. Około 1883 r. Brandel zaczął używać przenośnego aparatu fotograficznego własnej konstrukcji - był to w gruncie rzeczy prototyp wszystkich tego rodzaju urządzeń. Praktyka portretu fotograficznego stała się już dobrze znana i dość rozpowszechniona. Posyłano sobie pocztówki, których podstawą były zdjęcia. Kupowano w zakładach fotograficznych zdjęcia sławnych ludzi epoki. Fotografowanie się, posiadanie i oglądanie fotografii było praktyką dość powszechną.

Bohaterowie powieści Prusa jak gdyby o tym nie wiedzieli. Jak gdyby nie dotarły do nich dioramy, latarnie magiczne, panoramy, fotoplastikony, kosmoramy - nie oglądają, nie fotografują się, nie posiadają fotografii. Mówi się tylko o minia-

B. Prus, „Obrazy wszystkiego”. O literaturze i sztuce. Wybór $z$ „Kronik”. Wybór, wprowadzenie S. S a nd ler. Przypisy B. S zl e s zy ń s ki. Warszawa 2006, s. 448. (Pierwodruk: „Kurier Codzienny" 1887, nr 350, z 19 XII).

30 Ibidem, s. 483. (Pierwodruk: „Kurier Codzienny” 1888, nr 30, z 30 I). 
turze, którą zabrał ze sobą do grobu stryj Wokulskiego; jedyny wizerunek jest w powieści zaledwie wspomnieniem wizerunku.

O znaczeniu fotografii dla malarstwa wypowiadał się Prus sporo i kategorycznie. Jednak w powieści wizerunek i doświadczenie jego utrwalania czy oglądania - nie istnieją. W Literackich notatkach o kompozycji pisarz wielokrotnie podejmuje kwestię gatunków, w szczególności - powieści:

W ogóle przedstawia ona związek między człowiekiem, naturą i społeczeństwem, wyrobami i utworami.

$[\ldots]$

Jest to, słowem: obraz świata odmalowany pewną specjalną barwą. Jest to wiecznie ten sam świat czy jego pewna część, czy jakaś epoka, odbita w pewnym specjalnym zwierciadle. A zwierciadłem tym może być kamień, roślina, zwierzę, człowiek; albo - dowcip, miłość, nienawiść, nałóg, zasada itd., itd. Albo elektryczność, światło, ciepło, ciężkość itd. ${ }^{31}$

W tym krótkim fragmencie znamienne wydaje się to, jaką wagę autor przywiązuje do zjawisk optycznych: obraz świata, odmalowywanie, barwa, odbicie w zwierciadle, którym może być cokolwiek - także światło. Powieść nie ma więc mówić, opisywać - ma przedstawiać, odbijając jak w zwierciadle. Jest zatem tak, jak gdyby literatura znalazła się po stronie sztuk wizualnych.

Prus ceni zresztą wyżej cyfry niż litery. Prześledzenie tego to oddzielny wątek; choć ciekawy, nie zmieści się tutaj. Wywody felietonowe pisarza pełne są wyliczeń, proporcji, procentów, średnich, ciagów liczbowych. Literackie notatki o kompozycji sprawiają wrażenie, że są traktatem sporządzonym przez umysł poruszający się blisko jakiejś niebezpiecznej granicy - i wiele miejsca zajmują tam skomplikowane wyliczenia, które mają doprowadzić pisarza do osiagnięcia pożądanego efektu: prawdy. W powieściach Prusa częsty jest mechanizm wyjaśniania przez wyliczanie i - jak pamiętamy - nawet tajemnica przewag Paryża nad Warszawą zostaje wyłożona przez porównanie średnich temperatur rocznych w obydwu miastach i porachowanie, jaki naddatek kilokalorii posiada Paryż $-\mathrm{z}$ powodu panującego $\mathrm{w}$ nim ciepła. W jaki sposób dowiadujemy się o tym, że Wokulski myśli o Izabeli? Omija czytelników możliwy gest romantyczny: przyszły/niedoszły kochanek nie spogląda ukradkiem na wizerunek ukochanej. Wokulski pyta o księgę dłużników. Jeśli jest w niej Izabela, to jej transakcje uważa Wokulski w jakimś sensie za dobry znak być może, zapowiedź woli przystapienia do transakcji najistotniejszej, czyli małżeństwa. Czy ludziom w innych epokach to się zdarzało? Napawanie się subtelnymi wyobrażeniami przyszłego szczęścia miłosnego poprzez lekturę ksiag rachunkowych? „A chciała wziąc tę... - Ach, tę... - szepnął Wokulski, biorąc do ręki portmonetkę" (L-1 73). Zbliżył twarz do księgi, tak jakby zapis był niewyraźny; pytał o to, jak wybierała, czy przebierała, czy ta za trzy ruble to aby nie za droga. Ekstaza człowieka handlu: studiować zapis dłużny ukochanej, myśleć o niej - jak ogląda i dotyka towarów. Wszystko dla pań. Wszystko to tworzy przecież panie. W powieści Zoli zakupy, konsumpcja, wyprzedaż - to źródła kobiecej ekstazy. Więc wyobrażając sobie Izabelę konsumującą Wokulski, być może, widzi upragnioną

31 B. Pru s, Literackie notatki o kompozycji. Wstęp, wybór, oprac. A. Martus zew ska. Gdańsk 2010, s. 155. 
kobietę w chwili rozkoszy. Tyle że jest to rozkosz na miarę Warszawy: portmonetka za trzy ruble.

Podobnie Wokulski „obrachowuje” Izabelę na proszonym obiedzie - 15 rubli za materiał na suknię, koronki 10 , robocizna 15 , plus biżuteria i róża pąsowa ${ }^{32}$. Umiejętność liczenia jest zresztą dla niego w granicznym momencie życia testem - czy zachował jeszcze resztki zdrowia umysłowego.

Ażeby sprawdzić to, zaczął przypominać sobie tabliczkę mnożenia, potem mnożyć liczby dwucyfrowe przez jednocyfrowe i dwucyfrowe przez dwucyfrowe. Nie dowierzając sobie, zapisywał rezultaty działań, a potem sprawdzał je. Mnożenia na papierze zgadzały się z pamięciowym i Wokulski odetchnął.

„Jeszcze nie straciłem rozumu” - pomyślał z radością. [L-2 482]

Zapis księgowy jest tym, co zakotwicza człowieka w rzeczywistości, kolumna cyfr nie podlega sile złudzenia.

Wszystkie inne doświadczenia wizualne bohaterów Lalki są błąkaniem się w rzeczywistości, iluzjami, snami, przywidzeniami, odbiciami w zwierciadle.

Tomasz Łęcki podziwia siebie i córkę:

Objął ją [tj. Izabelę] w ramiona, ucałował w głowę i zanim usiadł przy niej, rzucił okiem w duże lustro na ścianie. Zobaczył tam swoją piękną twarz, siwe wąsy, swój ciemny żakiet bez zarzutu, gładkie spodnie, jakby dopiero co wyszły od krawca, i uznał, że wszystko jest dobrze. [L-1 105]

Na ścianach mieszkania Łęckich nie ma portretów przodków czy jakichkolwiek innych wizerunków, które można by oglądać. Jest tylko zwierciadło - dające przecież odbicie chwilowe i zmienne w czasie, nietrwałe. W następnym momencie odbicie zmienia się w malarską grupe, piękną kompozycję:

Przytuliła [Izabela] głowę do ramienia ojca. Pan Tomasz spojrzał niechcący w lusterko na stoliku i przyznał w duchu, że oboje w tej chwili tworzą bardzo piękną grupę. Szczególniej dobrze odbijała obawa rozlana na twarzy córki od jego spokoju. [L-1 105]

Izabela pamięta inne, szczególne doświadczenie - nie oglądania, lecz bycia oglądaną: Wokulski tak patrzył na nią, jak kiedyś gapiły się dzieci na nią i na Flo-

W Literackich notatkach o kompozycji pojawia się nawet „pasaż” zatytułowany Liczebna wartość człowieka. Zainspirowany artykułem J. Bloch a Ekonomiczna wytrzymałość państw wobec wojny („Biblioteka Warszawska” 1898, t. 2), Pr u s rozważa (s. 327), czy nie można by w podobny sposób oceniać człowieka. „Rozumie się, że moje rubryki są zupełnie inne” - zaznacza. I wymienia: „a) Majątek. b) Dochód. c) Długi. d) \pm Postęp w zbogacaniu się (dorobkie〈wicz〉, utracjusz). e) Wydatki. f) Ilość osób z nim majątkowo związanych (rodzina, służba). g) Wiek (Ile lat przeżył?). Prawdop〈odobieństwo〉 życia. h) Ile przeciętnie na rok przechodził chorób (dni chorób). i) Ile lat uczył się. j) Siła: rąk, nóg, tułowia, zębów, karku itd. zsumowana. k) Wzrost. 1) Waga. ł) Ile miał w życiu niezwykłych wypadków \pm U? m) Ilu przyjaciół, ilu wrogów? n) Ilu kobiet miłość. o) Ile \pm zalet: Umysłowych - Uczuciowych - Woli. p) Ile kilometrów przechodzi i przejeżdża rocznie? q) Ile kilogramów obrabia materiałów surowych? r) Ile wykonywa dzieł materialnych (sprzęty, listy, obuwie itd.). s) Ile zrobił odkryć i wynalazków? t) Ile przeszedł niebezpieczeństw. [...] u) Wartość liczebna zmysłów. w) Wartość org〈anów〉 odżywczych. x) Ile osób i rzeczy \pm kocha”. W innym miejscu Literackich notatek o kompozycji Prus porządkuje cechy fizyczne i duchowe człowieka, łącznie udało mu się ich naliczyć 25300 . Czy w wyniku tego wiadomo coś więcej? Wydaje się to wysoce wątpliwe i chyba Prus sam taką wątpliwość mocno odczuwał. Jego bohaterowie także - choć w liczeniu pokładają wielką nadzieję. Zob. esej $O$ pieniadzach $i$ kwestiach ekonomicznych $w$ "Lalce" z książki J. B a chór za Spotkania z „Lalka”. Mendel studiów i szkiców o powieści Bolesława Prusa (Gdańsk 2010). 
rę przez przeszklenie cukierni. I ze wspomnienia tego (opresywne spojrzenia $z$ zewnatrz, definiujace oglądanych jako prezentowany na wystawie przedmiot/towar) odtwarza (nie bez trafności) całą intrygę Wokulskiego - zmierzająca do usidlenia i nabycia jej, Izabeli, przy powszechnej akceptacji: ojca, hrabiny Karolowej.

Wokulski potrafi oglądać siebie z zewnątrz i nie potrzebuje do tego zwierciadła czy odbijającej światło szyby. Być może, na tej umiejętności - ustanawiania samego siebie we własnym spojrzeniu - zasadzają się resztki jego niezależności. Widzi siebie uczestniczącego w wielkanocnej kweście: „Boże! - pomyślał - jak ja głupio muszę wyglądać z tymi pieniędzmi” (L-1 172). Ma całkowita świadomość teatralności gestu - rzucenia na tacę brzęczącego złota „w czasach bankocetli”. Gdy przychodzi na świąteczne śniadanie do hrabiny, daje szwajcarowi pięć rubli i czuje, iż poczyna sobie jak parweniusz. Skąd człowiek wie takie rzeczy? Zwykle stąd, że potrafi oglądać siebie oczyma innych, projektować cudze spojrzenia, aspiruje do bycia nieparweniuszem. Na pierwszej kondygnacji miał kapelusz na głowie, na drugiej go zdją i nie wiedział, czy robi stosownie czy niestosownie „Jakimi to oni formami obwarowali się, co?” (L-1 188) - myśli i myśli też, że między nim a tym światem musi się rozegrać jakaś dramatyczna walka. „Rozstawili pikiety” - konkluduje Wokulski, bo drogę najpierw zastępuje mu Tomasz Łęcki, który go zagaduje, potem damy z hrabiną Karolową, gdzieś kręci się bez przerwy kamerdyner Józef - cały zaś ten kontredans odczytuje Wokulski jako rodzaj zmowy przeciwko sobie; „tańca”, który miał mu odebrać swobodę ruchów, a w każdym razie - uczynić przewidywalnym to, co nieprzewidywalne - „ażeby nie skompromitować dorobkiewicza” (L-1 191). Po zajściu z prezesową Zasławską boi się Wokulski defilady przez dwa salony - bo czekają tam na niego rózgi szeptów i spojrzeń. W Paryżu bardzo go dziwi to właśnie, że ludzie mu się nie przyglądają, że nie stanowi - wbrew temu, czego by się mógł spodziewać albo do czego jest przyzwyczajony - przedmiotu oględzin.

Warszawski kupiec dość często miewa różnego rodzaju przygody wizualne; i to są bardzo specyficzne widzenia oraz „słyszenia” - nierzadko literacko-operowe, powidoki jakichś wrażeń estetycznych. Na dworcu w Skierniewicach słyszy orkiestrę grająca inwokację z Roberta Diabła, popularnej opery Giacoma Meyerbeera. Scenę zdrady widzi także jako odbicie (kino? projekcję?):

Już chciał powstać z siedzenia, kiedy wypadkiem spojrzał w przeciwległą szybę wagonu i zobaczył w niej jak w lustrze słabe odbicie panny Izabeli i Starskiego. Siedzieli bardzo blisko siebie, oboje zarumienieni, choć rozmawiali tonem tak lekkim, jakby chodziło o rzeczy obojętne.

Wokulski jednakże spostrzegł, że obojętny ton nie odpowiada treści rozmowy [...]. [L-2 443]

Treść owej rozmowy nie jest mu jeszcze znana, nie rozumie jej, nie zaczął się wsłuchiwać w prowadzona po angielsku konwersację. S postrzega jednak, że jej ton jest niezgodny $z$ treścią.

Przycisnął się do ławki wagonu, patrzył w szybę i - słuchał. [...]

Już nie myślał ich ostrzegać, że rozumie, co mówią, tylko słuchał i słuchał... [L-2 443]

Pierwsze pokazy kinematograficzne odbywały się na ziemiach polskich w końcówce lat dziewięćdziesiątych w. XIX w Warszawie i w Krakowie ${ }^{33}$. Odcinkowa 
wersja Lalki była publikowana niemal dekadę wcześniej, nie można więc dopatrywać się u Prusa „doświadczenia obrazów filmowych”, „narracji filmowej w powieści” lub czegokolwiek w tym rodzaju. Nie wiem, czy jest możliwe udowodnienie, że czasem rzeczy występują w literaturze, zanim zaistnieją w rzeczywistości. Walter Benjamin zauważa:

Wielcy pisarze bowiem, wszyscy bez wyjątku, operują w świecie, który przyjdzie po nich, jak paryskie ulice $z$ wierszy Baudelaire’a pojawiły dopiero po przełomie wieków XIX i XX, a ludzie z Dostojewskiego też nie wcześniej ${ }^{34}$.

W przedstawionej tu scenie $z$ Lalki mamy jednocześnie: podróż pociąiem, tajemną rozmowę w przedziale kolejowym - dialog kochanków, podsłuchiwanie, a właściwie podglądanie, bo ostatecznie doświadczenie Wokulskiego nie jest przecież audialne, ale wizualne. Esencja nowoczesności: nieme kino w pociagu, i to jeszcze kino, w którym pokazuje się dobre gatunki popularne, dramat miłosny, w tle - muzyka z Roberta Diabła. Widz jest jednocześnie bohaterem dramatu, znajduje się tam, wewnątrz tej pełnej napięcia sceny, w której wykryta zostaje zdrada. W roku 1889 nie można było chyba tej sceny rozegrać lepiej - projekcja, odblask, szyba, przejrzystość i turkot pociągu stanowią idealne okoliczności.

Wokulski widzi siebie w lustrze jeden, jedyny raz - i to się dzieje w Paryżu, w hotelu, gdy się budzi i spostrzega, że nie jest sam. W łóżku naprzeciwko siedzi mężczyzna, który naśladuje jego, Wokulskiego, gesty. W pierwszej chwili jest to źródło pomieszania i przerażenia - bohater naprawdę doświadcza obecności innego, obcego, który na niego patrzy, czegoś, co wzbudza w nim wielki lęk.

O społeczeństwie spojrzeń pisze $z$ dużą trafnością Rousseau, jego myśl wykłada Bronisław Baczko w książce Rousseau: samotność i wspólnota ${ }^{35}$. Człowiek żyjący w społeczeństwie spojrzeń i opinii, w społeczeństwie wzajemnej kontroli, zostaje doprowadzony do stanu „wyzucia z siebie”. Jedyny rodzaj tożsamości, który posiada, to tożsamość domniemana - ustanawiana przez (hipotetyczne lub rzeczywiste) spojrzenia innych. Ten typ alienacji jest dla Rousseau najważniejszym, być może, wymiarem doświadczenia (miejskiej) nowoczesności:

Wyzwolenie od alienacji zachowuje zawsze u Rousseau swój aspekt moralny, jest problem em wy b oru, sa mo okréślenia się człowieka wobec samego siebie i świata. Wyalienowany charakter świata stosunków ludzkich, jego nieprzejrzystość, czynią go dla człowieka niejednoznacznym, światem jego własnym i zarazem obcym. Wolność osobowości manifestuje się w dążeniu do przezwyciężenia takiego właśnie charakteru świata i do uczynienia własnej egzystencji stabilną i jednoznaczną. A równocześnie jak długo świat zachowuje taki właśnie charakter, każde samookreślenie jednostki pozostaje wieloznaczne, pogłębia nieprzejrzystość nagromadzoną wokół niej, a jej „powrót do samej siebie” czyni wciąż niezakończonym i zagrożonym. Działanie w „świecie pozorów” włącza w łańcuch wydarzeń, na który jednostka nie ma wpływu, uzależnia ją od panujących anonimowych sił. Działanie staje się więc antynomiczne - będąc wyrazem wolności, zarazem jej zagraża ${ }^{36}$.

Czy jest wyjście z tej szczęśliwej nowoczesności? Cena za nią to konieczność życia na wystawie, w społeczeństwie panoptycznym, pod nieustanną kontrolą cu- 
dzych spojrzeń, a przynajmniej w stanie zagrożenia - i sądzę, że to przekonanie przenika myśl Prusa, niezależnie od tego, jaką myśl ta przyjmuje formę: powieść czy felieton.

W jednym $\mathrm{z}$ rozdziałów Lalki Izabela rozważa proteuszowy charakter Wokulskiego. Jawi się on jej jako człowiek, który w sposób swobodny i nieograniczony zmienia postać. Kim więc jest, że umyka sile „ustanawiającego spojrzenia”? Widziano go w Dąbrowie, jak kupował naboje, widziano w Zasławiu, może zginął, może się zapadł w zasławską studnię, może podróżuje dookoła świata, może pracuje nad metalem lżejszym od powietrza. Musze przyznać, choć chyba nie jest to całkiem stosowne, że zakończenie Lalki od wielu lat nie daje mi spokoju. Kolejne lektury powieści przekonują o tym, iż społeczność bohaterów powieści to esencja niepokojącej wizji społeczeństwa nowoczesnego. Wyciekło z niego wszelkie życie, została tylko - wzajemna władza spojrzeń. Nie ma innej od tego ucieczki niż iluzja. Sztuczka, zawieszenie projekcji, zniknięcie. Nie wątpię, że Wokulski byłby świetnym uczniem Johna Maskelyne’a. Gdzie jest znakomity warszawski kupiec? Pstryk! Zniknął. Unosi się nad miastem i robi sobie portret w gondoli balonu.

\section{Abstract \\ MAŁGORZATA LITWINOWICZ-DROŹDZIEL University of Warsaw \\ BOLESŁAW PRUS AND DOUBTFUL GLARE OF PROGRESS}

Industrialisation, cities concentration, technical progress and disseminating its results, emancipation processes of groups and social classes to date excluded from the dominating discourse, birth and development of the bourgeoisie - Prus touched upon all those issues continuously "testing" Polish society for the phenomena and categories listed above. The examination was usually unfavourable: Poles are in a state of civilisational backwardness and may become either mere consumers or followers of Western experiences, a society of peripheral modernisation.

The progress was supposed to bring about various valuable changes. However, as it seems, Prus' writing about the benefits of modernisation, along with a conviction (quite characteristic of the epoch) about inescapable happiness to which steam engine, railroad, telegraph and other discoveries and inventions contribute, fear and doubt are awakened. The creativity is primarily marked by a communicational drama taking place in the society in which interpersonal bonds now cease to exist. 